\title{
Cervix Glandular Epithelium
}

National Cancer Institute

\section{Source}

National Cancer Institute. Cervix Glandular Epithelium. NCI Thesaurus. Code C54414.

The epithelium of the endocervix, which consists of simple columnar cells. 